\title{
Geology of central and eastern North Greenland
}

\begin{abstract}
A. K. Higgins
Abstract

A historical review of geological research in North Greenland is followed by a summary of the main results of the 1978-80 GGU expeditions to the region.

New outcrops of Archaean and early Proterozoic crystalline rocks are recorded only as xenoliths in dykes and volcanic centres. A revised stratigraphy is applied to the middle Proterozoic Independence Fjord Group sandstones, while petrographic and isotopic studies have been made of the cross-cutting Midsommers $\emptyset$ dolerites and the overlying Zig-Zag Dal Basalt Formation. No convincing evidence has been found of a Carolinidian orogenic episode separating these units from succeeding late Proterozoic sedimentary sequences.

Lower Palaeozoic sediments dominate North Greenland and are divided into southern shelf and northern trough successions; new or revised stratigraphies are now applied in both settings. The shelf-trough boundary can be shown to have moved south with time, and a major early Silurian expansion of the trough is related to shelf subsidence and a new phase of turbidite deposition derived from the rising East Greenland Caledonian mountains.

Devonian - Middle Carboniferous (Ellesmerian) deformation brought deposition to a close and created the North Greenland fold belt, in which deformation intensity and metamorphic grade increase northwards. Thin-skinned thrusting in association with west or south-facing folds is important in southern areas; this is one of the main differences in interpretation compared to earlier work in the fold belt.

New outcrops of post-Ellesmerian sediments (Wandel Sea Basin) have mainly been recorded as fault or thrust bounded sequences; a new stratigraphy is applied to the Wandel Sea Basin succession. Cretaceous - Tertiary events include a suite of volcanic centres, dyke swarms, the Kap Washington Group volcanics, and faults and thrusts of Tertiary (Eurekan) age; all have been studied anew, as have the Quaternary deposits.
\end{abstract}

\section{Introduction}

Greenland, north of latitude $80^{\circ} \mathrm{N}$, is one of the world's most remote regions and generally difficult of access (fig. 1). A gradual increase in geological activity took place during the 1970s, much of it in preparation for the major GGU expeditions to central and eastern North Greenland in 1978-80 and central and western North Greenland in 1984-85. A brief review of the principal geological results of the 1978-80 expeditions is presented here (fig. 2).

\section{History of research}

The earliest geological investigations in North Greenland in the 19th century were incidental observations carried out by expeditions whose main aims were geographical discovery and exploration, and the conquest of the North Pole. By the beginning of the 20th century, when the land adjacent to Kennedy Channel and Robeson Channel had been visited by the expeditions led by E. K. Kane (1853-55), C. F. Hall (1871-73), G. S. Nares (1875-76) and A. W. Greely (1881-84), and the northernmost part of the Greenland coast had been reached by R. E. Peary in 1900, it was known that a zone of folded sand- 


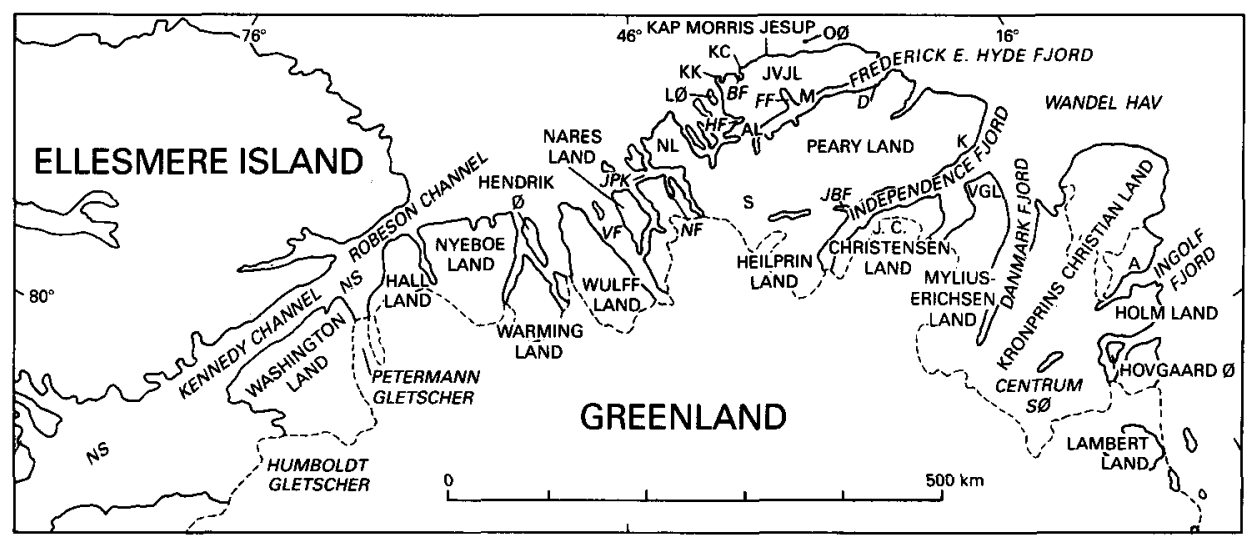

Fig. 1. Map of North Greenland, showing localities mentioned in the text. A - Amdrup Land; AL Amundsen Land; BF - Benedict Fjord; D - Depotbugten; FF - Frigg Fjord; HF - Harder Fjord; JBF Jørgen Brønlund Fjord; JPK - J. P. Koch Fjord; JVJL - Johannes V. Jensen Land; K - Kap København; KC - Kap Cannon; KK - Kap Kane; L $\emptyset$ - Lockwood Ø; M - Midtkap; NF - Navarana Fjord; NL - Nansen Land; OØ - Oodaaq $\emptyset$; S - Sydpasset; VF - Victoria Fjord.

stones and shales followed the north coast of Hall Land and Nyeboe Land, and that thick, unfolded, Palaeozoic carbonates were present to the south bordering the Inland Ice.

By 1912, when the 1st Thule expedition led by Knud Rasmussen crossed the Inland Ice from Thule and reported thick, flat-lying sandstones with basic intrusions around Independence Fjord, a two-fold division into northern folded and southern unfolded rocks had been established across North Greenland. The folded rocks had been reported in eastern Peary Land during the 1906-08 Danmark expedition by J. P. Koch and A. Bertelsen, while Ejnar Mikkelsen had made scattered observations in Kronprins Christian Land and around Danmark Fjord during the Alabama expedition (1909-12).

The first major, systematic, geological observations were made by Lauge Koch as cartographer and geologist on the 2nd Thule expedition (1916-18) led by Knud Rasmussen, and as leader of the Bicentenary Jubilee expedition (1920-23). The considerable cartographical and geological results of these expeditions included a 1:300 000 topographic map and a geological map series in five sheets; the latter included a 1:300 000 map of the south coast of Washington Land, a 1:500 000 map of northern Washington Land and a 1:2 000000 map of much of northern Greenland (Koch, 1929a, 1932; Dawes \& Haller, 1979). A stratigraphical division of the Lower Palaeozoic rocks was also made (Koch, 1920, 1929a, 1929b).

Apart from two flights by Lauge Koch over North Greenland in 1933 and 1938 with mainly cartographic objectives, the next significant geological observations were made by J. C. Troelsen in Washington Land during the Danish Thule and Ellesmere Land expedition (1939-41); Troelsen partly revised Koch's stratigraphy (Troelsen, 1956). At about the same time, Eigil Nielsen carried out some work in Kronprins Christian Land during the 1938-39 Danish Northeast Greenland expedition (Nielsen, 1941). Subsequently, two geologists, J. C. Troelsen and K. Ellitsgaard-Rasmussen, accompanied the 1947-50 Danish Peary Land expedition led by Eigil Knuth. Troelsen (1949) made important observations on Late Precambrian to Ordovician stratigraphy, including the discovery of tillites west of Jørgen Brønlund Fjord, and also on the nature of the cover sequence (Wandel Sea Basin) which overlies folded Lower Palaeozoic sediments in eastern Peary Land. Ellitsgaard-Rasmussen (1955) made significant observations on the North Greenland fold belt in western Nansen Land, and also on Proterozoic intrusions in 


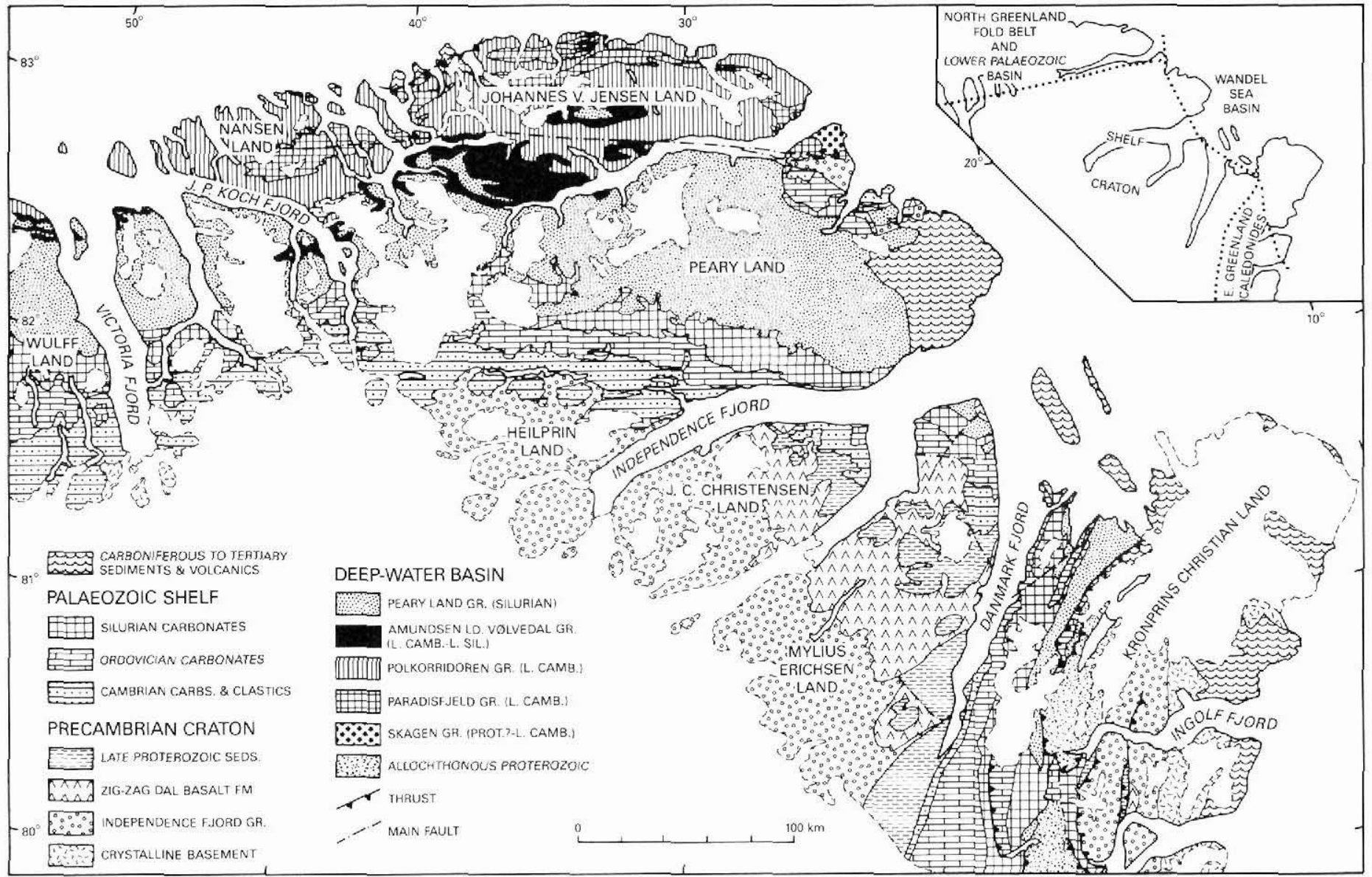

Fig. 2. Geological sketch map of North Greenland, based largely on work of the 1978-80 GGU expeditions. 
Heilprin Land (Ellitsgaard-Rasmussen, 1950). A few geologists attached to Lauge Koch's East Greenland expeditions also reached North Greenland: E. Fränkl and F. Müller made significant observations on structure and stratigraphy during a traverse of the fold belt between Frigg Fjord and Kap Morris Jesup in 1953 (Fränkl, 1955a); P. J. Adams and J. W. Cowie studied Palaeozoic rocks in the Danmark Fjord area in 1952 (Adams \& Cowie, 1953); and E. Fränkl established the general structure of the Caledonian fold belt in Kronprins Christian Land, also in 1952 (Fränkl, 1954, 1955b).

Regional geological studies, with emphasis on the Quaternary deposits, were made by W. E. Davies and D. B. Krinsley throughout North Greenland during the U.S. expedition, Operation Groundhog (1958-60) (Davies, 1963; Krinsley, 1961); this was also the first expedition to make use of helicopters in North Greenland.

GGU geologists (J. H. Allaart \& P. R. Dawes) visited North Greenland in 1965 and 1966 as part of the Geological Survey of Canada (GSC) expedition, Operation Grant Land, led by R. L. Christie. This was the first cooperative venture between GSC and GGU, and was aimed at study of the onshore geology of the two sides of Nares Strait. On the Greenland side of the strait, various studies were made in the region between Washington Land and Wulff Land.

H. F. Jepsen accompanied Eigil Knuth's Peary Land expeditions to southern Peary Land in 1966, 1968 and 1970 making studies of the late Precambrian and early Cambrian rocks (Jepsen, 1971), and in 1969 P. R. Dawes with N. J. Soper (University of Sheffield) joined the Joint Services Expedition, led by J. D. C. Peacock, and worked for four months on the folded Lower Palaeozoic rocks of northern Peary Land. 1969 also saw the start of the first geological reconnaissance work by a commercial enterprise; the Canadian prospecting company Greenarctic Consortium worked throughout North Greenland in the period 1969-73, and some of their more important results were incorporated in the review of North Greenland geology by Dawes (1976a).

The past decade has seen a steady increase in the tempo of GGU activity in North Greenland. In 1974, R. L. Christie (GSC) and J. S. Peel visited southern Peary Land in order to compile a reference section through the Lower Palaeozoic sequence, complementing the earlier work of J. C. Troelsen (Christie \& Peel, 1977). In 1975, J. S. Peel and N. Henriksen visited Washington Land, and revised Lauge Koch's and J. C. Troelsen's Cambro-Ordovician stratigraphy (Henriksen \& Peel, 1976). P. R. Dawes and A. Weidick accompanied the 1975 Greenland Ice Sheet Programme (GISP) operation to south-west Peary Land, making observations on Lower Palaeozoic stratigraphy including recognition of Middle Cambrian strata (Dawes, 1976b), and Quaternary observations (Weidick, 1976). In 1976 and 1977, parties including J. S. Peel, J. M. Hurst and H. F. Jepsen again visited Washington Land, undertaking studies and mapping of the Cambrian - Silurian rocks; a 1:250 000 map of Washington Land will shortly be published. Also in 1976, E. Håkansson and C. Heinberg worked on Triassic rocks of the Wandel Sea Basin in eastern Peary Land. All these activities were in part preparatory studies for the major, 5-year, systematic geological investigations which commenced in 1978.

By the beginning of 1978, a great deal of geological data in respect of North Greenland had thus been accumulated, although detailed geological maps existed only for a few of the more accessible areas. A regional geological map showing the distribution of the main rock groups had been prepared by $\mathbf{P}$. $\mathbf{R}$. Dawes at a scale of 1:1 000000 (Dawes, 1976a); this included information from all available sources, including an unpublished photogeological map by John Haller at a scale of 1:250 000. Apart from the GGU geological map of Washington Land, a map of Hall Land at 1:66 000 had also been completed, based largely on photogeological studies by P. R. Dawes, and S. A. S. Pedersen had prepared preliminary photogeological maps of much of central Peary Land. The greater part of North Greenland had, however, never been visited or had only been cursorily examined by geological parties prior to 1978 .

In the years 1978-80, systematic geological mapping and regional studies were carried out by between 10 and 12 two-man teams, mainly in eastern and central North Greenland. These GGU expeditions, led by Niels Henriksen, worked out of a tent base camp established at the mouth of Jørgen Brønlund Fjord which served as operation centre for two helicopters and a Twin Otter aircraft, and occasionally out of bases in Warming Land and at Centrum Sø. The GGU work was carried out in close cooperation with 
expeditions from the Geodætisk Institut (GI) which surveyed control points throughout North Greenland and with new aerial photography has prepared the first accurate topographic base maps of the region. The results of the GGU expeditions include a 1:500 000 geological map of Peary Land and four special 1:100 000 map sheets; in addition there has been a considerable increase in knowledge in virtually every aspect of North Greenland geology, resulting in a flood of new publications describing stratigraphy, structure and petrology. This paper reviews briefly some of the advances in geological knowledge arising from the 1978-80 expeditions to eastern and central North Greenland. GGU continued systematic work in central and western North Greenland in 1984 and 1985.

\section{Archaean - early Proterozoic crystalline basement}

Crystalline basement rocks are only sparsely represented in North Greenland, in situ outcrops being restricted to eastern Kronprins Christian Land (Jepsen \& Kalsbeek, 1981), and areas at the head of Victoria Fjord (Dawes, 1976a). The crystalline rocks in Kronprins Christian Land extend from Ingolf Fjord to Hovgaard $\emptyset$, continuing southwards to eastern Lambert Land, and include a variety of gneiss types, mica schist and amphibolite; a similar suite of rocks is known from the head of Victoria Fjord.

The nature of the crystalline basement underlying the Proterozoic and Palaeozoic sediments, which cover most of North Greenland, can be deduced indirectly. Erratic ice-transported blocks of gneissic and granitic rock types are locally common around the head of Independence Fjord, and isotopic studies of these suggest the presence in the basement of Archaean rocks, strongly affected by early Proterozoic metamorphism (Kalsbeek \& Jepsen, 1980; Kalsbeek, 1981). At Sydpasset in southern Peary Land, a $60 \mathrm{~m}$ by $10 \mathrm{~m}$ xenolith of leucocratic gneiss containing an amphibolite band occurs within a Proterozoic dolerite sheet (Kalsbeek \& Jepsen, 1980). Abundant basement inclusions occur within volcanic centres between Frigg Fjord and Midtkap (Pedersen, 1980; Soper et al., 1980; Parsons, 1981), including amphibolite, amphibolite-epidote rocks, amphibolite gneiss, acid gneiss and garnet-mica schist; the largest blocks are $100 \mathrm{~m}$ or more across. South of Benedict Fjord, close to the north coast of Johannes $V$. Jensen Land, granitic gneiss inclusions up to $30 \mathrm{~cm}$ across occur in a late Cretaceous dyke (Higgins et al., 1985). All these occurrences suggest that most of northernmost Greenland is underlain by continental crust, probably similar in nature to the Archaean - early Proterozoic crystalline rocks making up most of the Greenland shield (Kalsbeek, 1981).

\section{Middle Proterozoic rocks}

The oldest sediments of North Greenland are the 1750-2000 m thick sandstone sequence of the Independence Fjord Group (fig. 3), widely exposed on both sides of Independence Fjord. The stratigraphy has been revised in connection with new mapping (Collinson, 1980). The sandstones and siltstones north and west of Independence Fjord are still referred to the Inuiteq Sø Formation (Jepsen, 1971) and are divided into two members. The slightly different sequence south and east of Independence Fjord is now placed within the redefined Norsemandal Formation divided into three sandstone and two siltstone members. Sr-isotope studies on siltstones suggest deposition at approximately $1380 \mathrm{Ma}$ (Larsen \& Graff-Petersen, 1980).

In addition to the widespread occurrences of the Independence Fjord Group in southern 


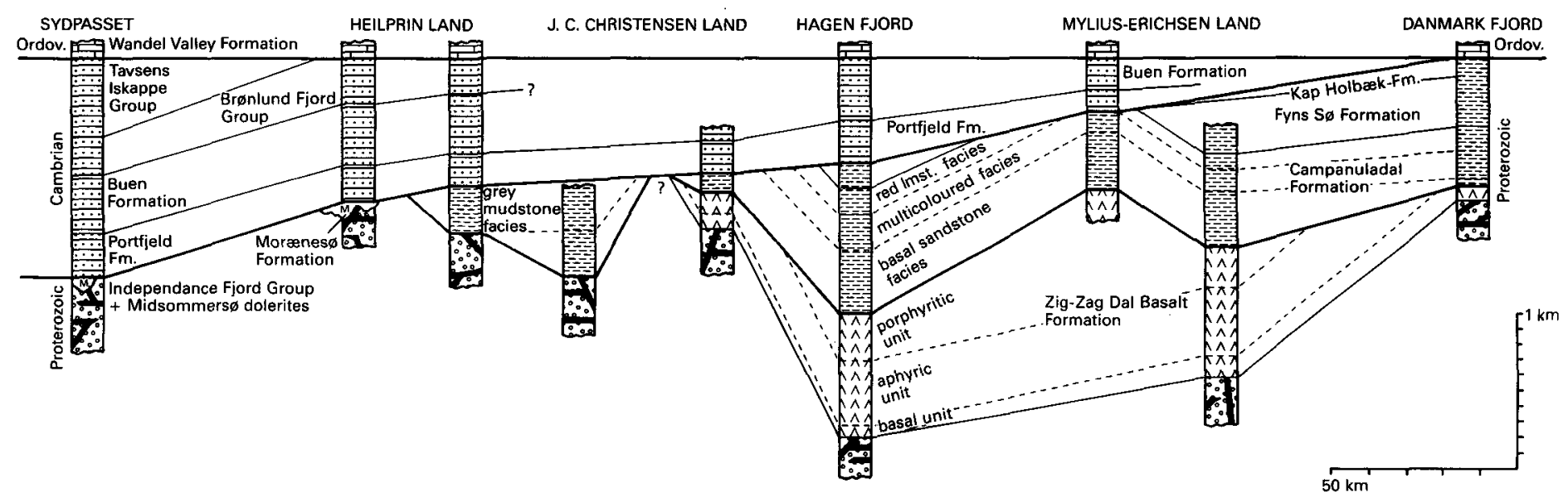

Fig. 3. Late Proterozoic - Cambrian stratigraphy of eastern North Greenland, showing major unconformities at the base of the Campanuladal Formation and the base of the Portfjeld Formation. Redrawn from compilation by H. F. Jepsen. 
Peary Land, west J. C. Christensen Land and south-west Mylius-Erichsen Land, Proterozoic sandstones correlated with the Independence Fjord Group are recorded in eastern Kronprins Christian Land (Jepsen \& Kalsbeek, 1981) and south of Depotbugten (Collinson, 1980).

Abundant basic intrusions within the Independence Fjord Group, which locally can make up $75 \%$ of fjord walls, are known as the Midsommers $\varnothing$ dolerites (Jepsen, 1971; Kalsbeek \& Jepsen, 1983). The intrusions occur as sills and dykes, often with very irregular outcrop patterns, and can be up to several hundred metres thick. Most are dark grey to black dolerites, while a second group of red brown to brick red intrusions grades from dolerite to granophyre; a third group of very silicic rocks is interpreted as mobilised sandstone (Kalsbeek \& Jepsen, 1983). Rb-Sr isochron ages of $1230 \mathrm{Ma}$ have been obtained on the intrusions (Kalsbeek \& Jepsen, 1983). The intrusion-bearing sandstones are overlain in some areas by the Zig-Zag Dal Basalt Formation which is considered probably to have been erupted during the same period of magmatic activity as that which gave rise to the sills and dykes.

Volcanic rocks were first reported from Mylius-Erichsen Land in 1969 by Greenarctic Consortium, but the extent and stratigraphy of what has become known as the Zig-Zag Dal Basalt Formation was determined during the 1978 and 1979 GGU expeditions (Jepsen et al., 1980). The formation is a Proterozoic sequence of tholeiitic flood basalts which may once have covered a large area of North Greenland, and is now known in a broad zone between Independence Fjord and Danmark Fjord. The petrography and chemistry of the basalts are described by Kalsbeek \& Jepsen (1984). The sequence is divided into three main units totalling up to $1350 \mathrm{~m}$ in thickness (fig. 3). However, large-scale erosion of the basalts occurred before deposition of the overlying Proterozoic Campanuladal Formation which, in northern J. C. Christensen Land, overlies only $100 \mathrm{~m}$ of basalt, and north and west of Independence Fjord rests directly on the Independence Fjord Group (Jepsen et al., 1980).

\section{Carolinidian orogeny disproved?}

In the course of Lauge Koch's geological expeditions to East and North-East Greenland in the period 1952-58, John Haller and co-workers made observations during field work and aerial reconnaissance mapping which suggested the existence of late Proterozoic ('Carolinidian') deformation predating the Caledonian orogeny (Haller, 1961, 1971). The existence of a Carolinidian fold belt was inferred mainly on the basis of a postulated angular unconformity within the Proterozoic sedimentary sequence, and from the suggested presence of two generations of Proterozoic basic intrusions, one generation apparently deformed by both the Carolinidian and Caledonian orogenies, and the other only by the latter.

Field work in 1980 has shown that there is an erosional unconformity between the Zig-Zag Dal Basalt Formation (and Independence Fjord Group) and overlying late Proterozoic sediments (fig. 3); however, the bedding in the two levels is parallel or subparallel with no indication of a deformation episode (Jepsen \& Kalsbeek, 1981, 1985). Also, the basic dykes and sills in the Independence Fjord Group seem to be affected by only one (Caledonian) phase of deformation.

Detailed field work thus suggests that the Carolinidian orogeny as defined by Haller (1961) has not affected the rocks of eastern North Greenland; Jepsen \& Kalsbeek state that no evidence has been found to support the concept of this late Proterozoic orogenic episode. Haller (1983), however, does not accept the complete dismissal of Proterozoic disturbances in the area by Jepsen \& Kalsbeek. 


\section{Late Proterozoic sediments}

The late Proterozoic sediments of North Greenland are assigned to the Rivieradal Sandstone, Campanuladal Formation, Fyns Sø Formation and Morænes $\varnothing$ Formation. They outcrop over a broad region between southern Peary Land and Kronprins Christian Land, and are in part lateral equivalents (fig. 3). Some of these formations were included by Haller (1970) in the 'Hagen Fjord Group'. There was a considerable pause in deposition following extrusion of the Zig-Zag Dal Basalt Formation, and the Precambrian land surface underwent extensive erosion. The late Proterozoic sediments thus rest unconformably on middle Proterozoic rocks everywhere, although without marked angular discordance.

The Rivieradal Sandstone (Fränkl, 1954, 1955b) is now interpreted as a $2500 \mathrm{~m}$ thick, turbiditic sandstone and mudstone sequence (Hurst \& McKerrow, 1981a, b). It occurs only in the Caledonian nappes of Kronprins Christian Land where it is overlain by the Campanuladal Formation.

Three well-defined facies associations are recognised in the Campanuladal Formation (sandstones, sandstones and siltstones, and limestones) in J. C. Christensen Land, eastern Valdemar Glückstadt Land and Kronprins Christian Land (Clemmensen, 1979); they total up to about $800 \mathrm{~m}$ in thickness. North of Independence Fjord, the age equivalent deposits are a grey mudstone facies.

The Fyns Sø Formation (Adams \& Cowie, 1953; Clemmensen, 1979), composed of cliffforming yellow dolostones, outcrops between southern Danmark Fjord and northern J. C. Christensen Land. It is represented by a sequence of stromatolitic dolomites in the Caledonian nappes of Kronprins Christian Land (Hurst \& McKerrow, 1981a, b). The upper boundary is an erosional peneplaned surface, and the Fyns $\$ \varnothing$ Formation is overlain by the Lower Cambrian Portfjeld Formation west of Danmark Fjord and the Kap Holbæk Formation east of Danmark Fjord (fig. 3).

The Morænes $\varnothing$ Formation is best known in southern Peary Land west of the head of Jørgen Brønlund Fjord (Jepsen, 1971; Clemmensen, 1979, 1981); further outcrops were discovered around the head of Victoria Fjord in 1984 (H. F. Jepsen, personal communication, 1984). Locally up to $100 \mathrm{~m}$ thick in southern Peary Land, its thickness is variable due to preservation in palaeodepressions at the lower erosional contact. A glacial origin for the massive tillites first suggested by Troelsen (1950) is supported by their lack of sorting, clast shape and striated stones, while some pebbly sandstones earlier included in the tillite sequence are interpreted as fluvio-lacustrine or aeolian in origin (Clemmensen, 1981).

\section{Lower Palaeozoic shelf-trough system}

Throughout most of the Lower Palaeozoic a distinction can be made in much of North Greenland between shelf, mainly carbonate, deposition to the south and deposition in a deep-water trough to the north. The shelf carbonate sequence is about $3 \mathrm{~km}$ thick, and the equivalent trough sequence at least $8 \mathrm{~km}$ thick. The new GGU work has led to new or revised stratigraphies for both the shelf and trough (fig. 4), and to developments of models illustrating the evolution of the deep-water trough system (Surlyk \& Hurst, 1983, 1984).

The E-W trending Lower Palaeozoic deep-water trough of North Greenland continues westwards into the Hazen trough of northern Ellesmere Island, a part of the 'Franklinian geosyncline' of Schuchert (1923). In both North Greenland and northern Ellesmere Island, 


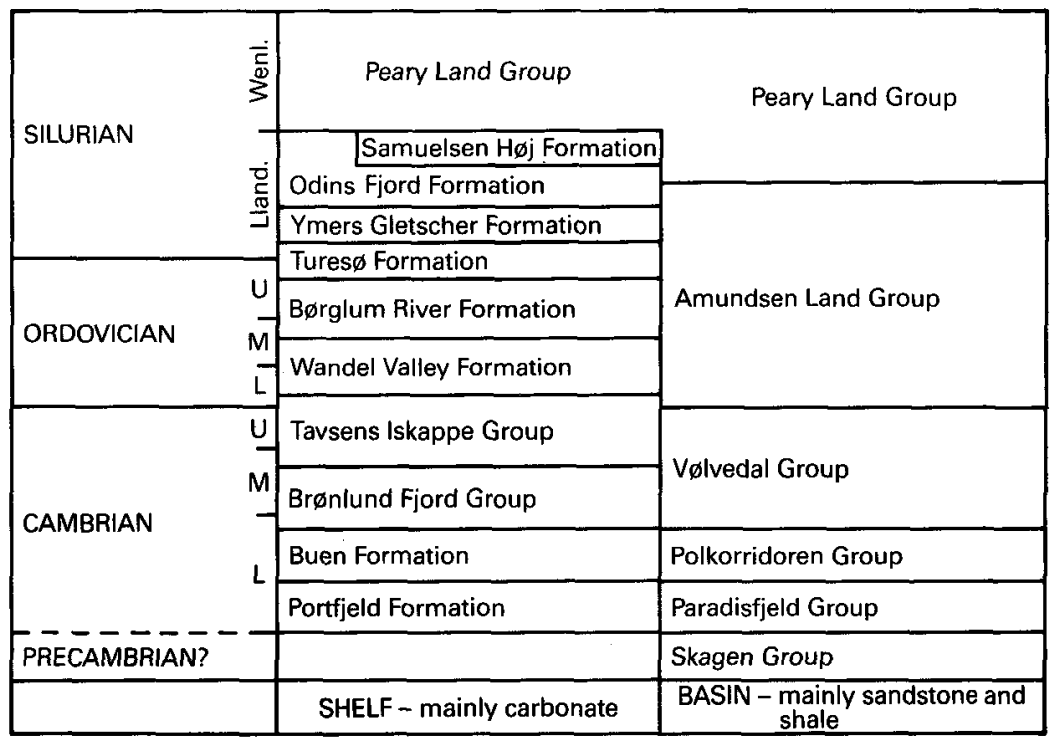

Fig. 4. Stratigraphical scheme of the Lower Palaeozoic shelf and basin sequences of the Peary Land region.

the Lower Palaeozoic trough sequence shows the same general development; Lower Cambrian turbidite deposition was succeeded by late Lower Cambrian - Lower Silurian starved slope/basin carbonates, cherts and turbidites, and a new phase of thick turbidite deposition took place in the Silurian. An expansion of the Silurian basin is also noted in both regions, but in Ellesmere Island it took place in the Pridoli - Lower Gedinnian (uppermost Silurian Lower Devonian) (Trettin, 1979; Trettin \& Balkwill, 1979), somewhat later than in Greenland where it is dated at the Llandovery - Wenlock boundary (Lower Silurian - Middle Silurian) (Surlyk et al., 1980; Surlyk \& Hurst, 1983, 1984).

Models of the shelf - trough transition in North Greenland (Surlyk et al., 1980; Surlyk \& Hurst, 1983, 1984) based on detailed sedimentary logs and facies interpretation envisage the shelf margin to have been controlled by major E-W faults (Harder Fjord fault zone, Navarana Fjord fault), with southward expansion of the trough during Lower Palaeozoic time due to collapse of the shelf margin along these faults. Structural studies suggest some caution in this interpretation (Higgins et al., 1981, 1985). While some of the lineaments responsible for control of sedimentation during the Lower Palaeozoic are easily defined, the identity of others is not clear, since some of the structures have been shown to be main elements of thin-skinned Ellesmerian thrusts or Eurekan faults. However, these later thrusts and faults may have had precursors which did influence Lower Palaeozoic sedimentation.

\section{Lower Palaeozoic shelf}

Cambrian shelf strata in the Peary Land - Kronprins Christian Land region are most fully developed in Peary Land where the sequence is almost $1500 \mathrm{~m}$ thick; the sequence is only $150 \mathrm{~m}$ thick around Danmark Fjord (Peel, 1982). The lowest Cambrian formation, the 
mainly dolomitic Portfjeld Formation, overlies the late Proterozoic Morænes $\emptyset$, Campanuladal or Fyns $\$ \emptyset$ Formations; the base of the Portfjeld Formation is an important erosional peneplaned surface (fig. 3). The Portfjeld Formation is overlain by the shales and sandstones of the Lower Cambrian Buen Formation. Most of the Cambrian formations of Peary Land are assigned to the Brønlund Fjord Group and Tavsens Iskappe Group, a prograding complex of carbonates, sandstones and shales showing substantial facies variations (Ineson \& Peel, 1980).

Ordovician shelf carbonates are principally referred to the Wandel Valley Formation and Børglum River Formation, originally described from the Jørgen Brønlund Fjord area (Troelsen, 1949; Christie \& Peel, 1977). The Ordovician - Silurian boundary lies within the overlying dolomite unit, recently defined as the Tures $\emptyset$ Formation (Hurst, 1984). In Kronprins Christian Land, the entire Lower Palaeozoic carbonate sequence was named the 'Centrum Limestone' by Adams \& Cowie (1953), but Peel et al. (1981) have demonstrated the essential continuity of the Ordovician sequence in the two areas, and a regionally applicable stratigraphy is now used.

The relationship between shelf and deep-water stratigraphy is complex, and where the platform margin is characterised by carbonate mounds there are considerable facies variations. In Peary Land, a steep scarp-like platform margin is inferred in the Lower Silurian (Surlyk \& Hurst, 1983, 1984; Hurst \& Surlyk, 1984). Carbonate accumulation continued on the shelf of Peary Land until the end of the Lower Silurian, with deposition of the Ymers Gletscher Formation and Odins Fjord Formation, and the carbonate mounds of the Samuelsen Høj Formation (Hurst, 1984). Subsequently, flysch deposition overwhelmed the shelf following the southerly expansion of the trough.

\section{Lower Palaeozoic trough}

The main part of the $c .8 \mathrm{~km}$ deep-water succession in North Greenland is Cambrian - Silurian in age, but it may extend down into the late Proterozoic and up into the Devonian. Fossils are very rare in the Cambrian part of the sequence, now largely preserved in the northern areas most severely affected by Ellesmerian (Devonian - Middle Carboniferous) deformation. The youngest rocks known in the basin sequence are uppermost Silurian (or lowermost Devonian?) mudstones and limestones in Hall Land (Bendix-Almgreen \& Peel, 1974; Berry et al., 1975). Six lithostratigraphic groups are now recognised in the Peary Land region (Friderichsen et al., 1982) (fig. 4), revising and integrating early stratigraphic schemes, and each of them can be linked to stages in the evolution of the trough (Surlyk \& Hurst, 1983, 1984). The Silurian sediments of the Peary Land Group have been described in terms of constituent formations (Hurst \& Surlyk, 1982), whereas detailed description and designation of formations of the Cambrian and Ordovician groups awaits completion of field work in 1984 and 1985.

The Lower Cambrian part of the sequence is represented by the (Proterozoic? - Lower Cambrian) Skagen Group (sandstone and shale), Paradisfjeld Group (carbonate, calcareous shale, limestone conglomerate) and Polkorridoren Group (sandstone, siltstone and mudstone turbidites). They exhibit marked facies variations, and lithostratigraphic interpretation is hindered by the often intense deformation. Fragmentary fossils of Cambrian age are known from the top of the Paradisfjeld Group (Peel \& Higgins, 1980), while trace fossils are locally common in the Polkorridoren Group (Pickerill et al., 1982). Mapping in 1984 has 
confirmed the correlation of the Paradisfjeld Group and Polkorridoren Group with, respectively, the Portfjeld Formation and Buen Formation of the platform sequence, as suggested by Surlyk et al. (1980).

The late Lower Cambrian - Ordovician (?Lower Silurian) is mainly represented in the Peary Land region by the Vølvedal and Amundsen Land Groups, a sequence of cherts, mudstones, turbiditic sandstones and siltstones, and redeposited conglomerates derived from the platform to the south. The sequence is mainly exposed in the southern part of the North Greenland fold belt, in Amundsen Land and along the north side of inner Frederick E. Hyde Fjord. Work in 1984 shows that the sandstone turbidites of the Vølvedal Group do not occur in the preserved outcrops in western North Greenland, where the late Lower Cambrian - Lower Silurian sequence comprises a starved outer shelf or slope sequence of carbonates (mainly dolomites and dolomitic mudstones) and cherts, very similar in development and age to the Hazen Formation of northern Ellesmere Island (Trettin \& Balkwill, 1979).

The Silurian sediments of the Peary Land Group, which represent a new phase of major sandstone turbidite deposition, are widely exposed throughout North Greenland. The sequence is divided into eight formations, interpreted as deposits of the upper to lower slope, submarine fan and basin plain environments (Hurst \& Surlyk, 1982). The sequence includes major sandstone, mudstone and conglomerate units. Transport directions are east to west over North Greenland (Hurst \& Surlyk, 1982), and reflect derivation of detritus from the rising Caledonian mountains in the east (Surlyk, 1982; Hurst et al., 1983). The expansion of the trough in the latest Llandovery is also linked to Caledonian events (see below).

\section{Caledonian fold belt}

Only the northern extremity of the Caledonian fold belt in Kronprins Christian Land has been visited by the 1978-80 GGU expeditions, where the general structure of westward directed thrusts known from earlier work (Fränkl, 1954, 1955b) has been confirmed. However, three large nappe units are now recognised (Hurst \& McKerrow, 1981a, b), containing late Proterozoic and Lower Palaeozoic clastic and carbonate sediments. Facies variations imply the nappes have westwards displacements of at least $150 \mathrm{~km}$ (Hurst et al., 1983). In the west the nappes are in thrust contact with folded Ordovician and Silurian platform carbonates and Silurian turbiditic sandstones.

One of the most interesting aspects of the Caledonian fold belt to emerge from the new regional mapping, is the link between the uplift of the Caledonian mountains and Silurian turbidite sedimentation in North Greenland. It is suggested that erosion of the rising mountains and advancing Caledonian nappes provided much of the source of clastic detritus for the Silurian turbidites (Surlyk, 1982), and also that depression of the crust ahead of the nappes led directly to foundering of the carbonate platform and the expansion of basinal turbidite deposition in the latest Llandovery (Hurst et al., 1983).

\section{Ellesmerian orogeny - North Greenland fold belt}

Deposition in North Greenland was brought to a close in the latest Silurian or earliest Devonian by the Ellesmerian orogeny which affected large areas of Arctic Canada and North Greenland in the Devonian - Middle Carboniferous. In North Greenland, the E-W trending North Greenland fold belt developed on the site of the Lower Palaeozoic deep-water basin. 
Detailed structural studies have largely confirmed the interpretations of Dawes \& Soper (1973); three main phases of coaxial folding are recognised in Johannes V. Jensen Land, showing pronounced northwards overturning and northwards increase in deformation intensity, accompanied by amphibolite facies metamorphism in the extreme north (Soper et al., 1980; Higgins et al., 1981, 1985).

In the southern part of the fold belt, in Amundsen Land and north of inner Frederick E. Hyde Fjord, an early phase of deformation is characterised by a spectacular pattern of imbricate thrusts and associated folds with anomalous strikes which swing from $\mathrm{N}-\mathrm{S}$ trends immediately south of the Harder Fjord fault zone, through NW-SE to the normal E-W trend of the fold belt (Pedersen, 1980). The structures appear to be thin-skinned, with a décollement in the Frigg Fjord mudstones and a westwards sense of displacement. Interpretations of their origin include: gravity megasliding off the rising Caledonides $200 \mathrm{~km}$ to the east (Pedersen, 1981, 1982), a model rejected for various reasons by Surlyk \& Hurst (1984); and thrusting associated with sinistral transpression on the Harder Fjord fault zone (Surlyk \& Hurst, 1984), considered improbable by Higgins et al. (1985) as the only displacements known on the Harder Fjord fault zone are post-Ellesmerian and dextral.

South-facing major folds occur along the south margin of the fold belt south of Frederick E. Hyde Fjord (Dawes, 1971; Dawes \& Soper, 1979; Pedersen, 1979). Photogeological studies and field work in 1984 have revealed that these folds are part of an important belt of asymmetric south-facing folds which extend for at least $400 \mathrm{~km}$ westwards across North Greenland to Nyeboe Land. Over much of this distance, north dipping minor thrusts with southwards sense of displacement are associated with the folds, and a major north dipping thrust zone is inferred to coincide with the change in vergence from north-facing folds in the northern part of the fold belt to south-facing folds in the southern part of the fold belt.

\section{Wandel Sea Basin}

Carboniferous - Neogene sediments rest unconformably on the Lower Palaeozoic platform carbonates, and on the deformed rocks of the East Greenland Caledonides and North Greenland fold belt. The oldest parts of these sequences are continental early Carboniferous rocks found on Holm Land (Nathorst, 1911). These cover sequences are referred to the Wandel Sea Basin, of which recent descriptions include those of Håkansson (1979), Håkansson et al. (1981) and Birkelund \& Håkansson (1983). The most extensive exposures are found in eastern Peary Land, northern Kronprins Christian Land and adjacent islands, the land areas bordering Wandel Hav (Wandel Sea). Small occurrences occur as down-faulted slices along the Harder Fjord fault zone, and associated with the Kap Washington Group volcanics beneath the Kap Cannon thrust zone (see below), and may be the few remnants of a once continuous cover sequence.

The Carboniferous - Permian part of the sequence is referred largely to the Mallemuk Mountain Group (Håkansson, 1979); two new formations are established in eastern Peary Land where the sequence of conglomerates, sandstones, grey limestones and cherts is 1100 $m$ thick. Thick sequences occur in a variety of facies in Holm Land and Amdrup Land in the south-east, and on Lockwood $\varnothing$ and Kap Kane in the extreme north (Håkansson et al., 1981).

Clastic Permo-Triassic sediments in eastern Peary Land are referred by Håkansson (1979) to the Trolle Land Group, a new group of dominantly sandstones and shales divided into 
three formations, and more than $1000 \mathrm{~m}$ thick. Farther north-west, north of Midtkap in the Harder Fjord fault zone, a several hundred metres thick sequence of conglomerate, sandstone and coaly shale contains a well preserved Late Permian flora of Pechora affinity (Wagner et al., 1982).

Mesozoic and Tertiary sediments (mainly conglomerates, sandstones and shales) are well represented in Kronprins Christian Land and eastern Peary Land; isolated thrust or fault bounded outcrops also occur on Lockwood $\emptyset$, east of Frigg Fjord and at Depotbugten (Batten et al., 1981; Birkelund \& Håkansson, 1983; Croxton et al., 1980; Håkansson et al., 1981).

\section{Volcanic centres, dyke swarms and the Kap Washington Group}

Intrusive and extrusive events in North Greenland may all be related to the Cretaceous Tertiary history of the region, although the age of a group of volcanic centres between Frigg Fjord and Midtkap is still uncertain. The main group of these volcanic centres, discovered as late as 1979 , lies $3-8 \mathrm{~km}$ south of, and roughly parallel to, the Harder Fjord fault; individual centres range from a hundred metres to about $2 \mathrm{~km}$ in diameter (Soper et al., 1980; Pedersen, 1980). All are interpreted as discordant volcanic pipes by Parsons (1981), filled by a variety of brecciated blocks, including local sediments, basement metamorphic rocks and igneous rocks, and associated with a suite of highly altered basic volcanics, gabbros and serpentinites; exotic blocks range in size from several hundred metres across down to microscopic. A single Middle Devonian K-Ar age on biotite from a dioritic block from one of the centres (Pedersen \& Holm, 1983) is considered to be of uncertain significance.

Alkali dolerite dykes of Late Cretaceous age are widespread in North Greenland east of Victoria Fjord. A swarm of NNE to NNW trending dykes about $100 \mathrm{~km}$ wide occurs in Nansen Land and Johannes V. Jensen Land north of the Harder Fjord fault zone. In and south of the fault zone, this swarm is replaced by WNW-ESE trending dykes, and farther south by occasional NW-SE dykes. Petrographically, the dykes are alkali dolerites, and chemically have an alkaline character (Soper et al., 1982). They are considered related chemically to the peralkaline Kap Washington Group volcanic rocks and therefore of similar age, but as they do not penetrate the volcanics, are referred to a period of crustal extension immediately preceding the volcanic episode (Batten et al., 1981; Brown \& Parsons, 1981).

The Kap Washington Group volcanics outcrop over a limited area of the north coast of North Greenland (Brown \& Parsons, 1981), more restricted than suggested on the map of Dawes (1976a). The outcrop of the sequence is bounded to the south by the Tertiary Kap Cannon thrust zone. The volcanic sequence is at least $5 \mathrm{~km}$ thick, and characterised by its peralkaline chemistry (Batten et al., 1981; Brown \& Parsons, 1981); hawaiitic, trachytic and rhyolitic lavas, tuffs and breccias are recorded, as well as felsite plugs and dykes. Pollen and spores from sediments interbedded with the volcanics (Batten et al., 1981; Batten, 1982) and a Rb-Sr isochron age of $64 \pm 3 \mathrm{Ma}$ (Larsen, 1982) indicate an age close to the CretaceousTertiary boundary.

\section{Eurekan orogeny}

Structures of Tertiary age are superimposed on Ellesmerian structures in a regional tectonic zone extending from the Canadian Arctic Islands (Eurekan orogeny: Thorsteinsson \& Tozer, 1970; Trettin et al., 1972) through North Greenland and possibly to Svalbard. In 
North Greenland the extent and intensity of this deformation phase is still uncertain due to the limited distribution of post-Ellesmerian sediments; the main Eurekan structures appear to be the Kap Cannon thrust zone and Harder Fjord fault zone in Johannes V. Jensen Land (Soper et al., 1982), and the Trolle Land fault system in eastern Peary Land and northern Kronprins Christian Land (Håkansson \& Pedersen, 1982).

Relationships between the Cretaceous - Tertiary magmatic and tectonic events in North Greenland and the history of development of the Atlantic and Arctic Oceans have been suggested by Batten et al. (1981) and Soper et al. (1982). In a presentation of the Late Palaeozoic to Tertiary tectonic evolution of North Greenland and adjacent regions (Håkansson \& Pedersen, 1982), also based largely on the new GGU work, misleadingly large strike-slip displacements (as much as $700 \mathrm{~km}$ ) are attributed to the Harder Fjord fault zone; vertical displacement of up to $2000 \mathrm{~m}$ (Higgins et al., 1985), and a dextral strike-slip component of about $20 \mathrm{~km}$ seem likely on the basis of correlation of Ellesmerian structures and Lower Palaeozoic stratigraphical units across the fault. Along the north coast of North Greenland, the Kap Washington Group volcanic rocks and associated Wandel Sea Basin sediments are underthrust along the Kap Cannon thrust zone beneath highly deformed Lower Palaeozoic metasediments; a possible late Paleocene - Eocene age is suggested for this event (Soper et al., 1982).

\section{Quaternary}

Studies of the Quaternary geology (Funder \& Hjort, 1980) have been aimed at establishing a stratigraphic framework which would make possible compilation of a 1:500 000 Quaternary map. The limit of maximum ice cover has been localised, and the concept of two distinct ice accumulations proposed by earlier workers confirmed; an extension of the Inland Ice reached into southern Peary Land, while an independent ice cap covered central and northern Peary Land. A $100 \mathrm{~m}$ sequence of unconsolidated pre-Holocene sediments at Kap København has been the subject of detailed investigations (Funder \& Hjort, 1980; Funder $e t$ $a l ., 1984)$. It contains abundant well-preserved plant and animal remains, probably Pliocene or Pleistocene in age. The sediments of the Kap København Formation include clay, silt, sand and locally gravel, and are interpreted as marine deposits (Funder et al., 1984). The world's northernmost land, Oodaaq $\varnothing, 30 \mathrm{~m}$ in diameter and one metre high, discovered by a Geodætisk Institut party in 1978, is a beach ridge resting on marine sediments (Andersson et al., 1980).

Acknowledgements. P. R. Dawes, H. F. Jepsen, N. J. Soper and F. Surlyk kindly made useful comments on early drafts of this manuscript.

\section{References}

Adams, P. J. \& Cowie, J. W. 1953: A geological reconnaissance of the region around the inner part of Danmarks Fjord, Northeast Greenland. Meddr Grønland 111(7), 24 pp.

'Andersson, H., Funder, S. \& Hjort, C. 1980: På verdens nordligste landjord. Naturens Verden 10, 314322.

Batten, D. J. 1982: Palynology of shales associated with the Kap Washington Group volcanics, central North Greenland. Rapp. Grønlands geol. Unders. 108, 15-23. 
Batten, D. J., Brown, P. E., Dawes, P. R., Higgins, A. K., Eske Koch, B., Parsons, I. \& Soper, N. J. 1981: Peralkaline volcanicity on the Eurasia Basin margin. Nature 294, 150-152.

Bendix-Almgreen, S. E. \& Peel, J. S. 1972: Early Devonian vertebrates from Hall Land, North Greenland. Rapp. Grønlands geol. Unders. 65, 13-16.

Berry, W. B. N., Boucot, A. J., Dawes, P. R. \& Peel, J. S. 1974: Late Silurian and early Devonian graptolites from North Greenland. Rapp. Grønlands geol. Unders. 65, 11-13.

Birkelund, T. \& Håkansson, E. 1983: The Cretaceous of North Greenland - a stratigraphic and biogeographical analysis. Zitteliana 10, 7-25.

Brown, P. E. \& Parsons, I. 1981: The Kap Washington Group volcanics. Rapp. Grønlands geol. Unders. 106, 65-68.

Christie R. L. \& Peel, J. S. 1977: Cambrian - Silurian stratigraphy of Børglum Elv, Peary Land, eastern North Greenland. Rapp. Grønlands geol. Unders. 82, 42 pp.

Clemmensen, L. B. 1979: Notes on the palaeogeographical setting of the Eocambrian tillite-bearing sequence of southern Peary Land, North Greenland. Rapp. Grønlands geol. Unders. 88, 15-22.

Clemmensen, L. B. 1981: Late Precambrian tilloids of Peary Land. In Hambrey, A. J. \& Harland, W. B. (edit.) Earth's pre-Pleistocene glacial record, 782-786. Cambridge Univ. Press.

Collinson, J. D. 1980: Stratigraphy of the Independence Fjord Group (Proterozoic) of eastern North Greenland. Rapp. Grønlands geol. Unders. 99, 7-24.

Croxton, C. A., Dawes, P. R., Soper, N. J. \& Thomsen, E. 1980: An occurrence of Tertiary shales from the Harder Fjord Fault, North Greenland fold belt, Peary Land. Rapp. Grønlands geol. Unders. 101, 61-64.

Davies, W. E. 1963: Glacial geology of northern Greenland. Polarforschung 5(31), 94-103.

Dawes, P. R. 1971: The North Greenland fold belt and environs. Bull. geol. Soc. Denmark 20, 197-239.

Dawes, P. R. 1976a: Precambrian to Tertiary of northern Greenland. In Escher, A. \& Watt, W. S. (edit.) Geology of Greenland, 248-303. Copenhagen: Geol. Surv. Greenland.

Dawes, P. R. 1976b: Reconnaissance of Eocambrian and Lower Palaeozoic strata in south-western Peary Land, North Greenland. Rapp. Grønlands geol. Unders. 80, 9-14.

Dawes, P. R. \& Haller, J. 1979: Historical aspects in the geological investigation of northern Greenland. Part 1: New maps and photographs from the 2nd Thule Expedition 1916-1918 and the Bicentenary Jubilee Expedition 1920-1923. Meddr Grønland 200(4), 33 pp.

Dawes, P. R. \& Soper, N. J. 1973: Pre-Quaternary history of North Greenland. In Pitcher, M. G. (edit.) Arctic geology. Mem. Am. Ass. Petrol. Geol. 19, 117-134.

Dawes, P. R. \& Soper, N. J. 1979: Structural and stratigraphic framework of the North Greenland fold belt in Johannes V. Jensen Land, Peary Land. Rapp. Grønlands geol. Unders. 93, 40 pp.

Ellitsgaard-Rasmussen, K. 1950: Preliminary report on the geological field work carried out by the Danish Peary Land Expedition in the year 1949-50. Meddr Dansk geol. Foren. 11, 589-595.

Ellitsgaard-Rasmussen, K. 1955: Features of the geology of the folding range of Peary Land, North Greenland. Meddr Grønland 127(7), $56 \mathrm{pp.}$

Fränkl, E. 1954: Vorläufige Mitteilung über die Geologie von Kronprins Christians Land (NE-Grönland). Meddr Grønland 116(2), 85 pp.

Fränkl, E. 1955a: Rapport über die Durchquerung von Nord Peary Land (Nordgrönland) im Sommer 1953. Meddr Grønland 103(8), 61 pp.

Fränkl, E. 1955b: Weitere Beiträge zur Geologie von Kronprins Christians Land (NE-Grönland). Meddr Grønland 103(7), 35 pp.

Friderichsen, J. D., Higgins, A. K., Hurst, J. M., Pedersen, S. A. S., Soper, N. J. \& Surlyk, F. 1982: Lithostratigraphic framework of the Upper Proterozoic and Lower Palaeozoic deep water clastic deposits of North Greenland. Rapp. Grønlands geol. Unders. 107, 19 pp.

Funder, S. \& Hjort, C. 1980: A reconnaissance of the Quaternary geology of eastern North Greenland. Rapp. Grønlands geol. Unders. 99, 99-105.

Funder, S., Bennike, O., Mogensen, G. S., Noe-Nygaard, B., Pedersen, S. A. S \& Petersen, K. S. 
1984: The Kap København Formation, a late Cainozoic sedimentary sequence in North Greenland. Rapp. Grønlands geol. Unders. 120, 9-18.

Håkansson, E. 1979: Carboniferous to Tertiary development of the Wandel Sea Basin, eastern North Greenland. Rapp. Grønlands geol. Unders. 88, 73-83.

Håkansson, E. \& Pedersen, S. A. S. 1982: Late Paleozoic to Tertiary tectonic evolution of the continental margin in North Greenland. In Embry, A. F. \& Balkwill, H. R. (edit.) Arctic geology and geophysics. Mem. Can. Soc. Petrol. Geol. 8, 331-348.

Håkansson, E., Heinberg, C. \& Stemmerik, L. 1981: The Wandel Sea Basin from Holm Land to Lockwood $\varnothing$, eastern North Greenland. Rapp. Grønlands geol. Unders. 106, 47-63.

Haller, J. 1961: The Carolinides: an orogenic belt of late Precambrian age in Northeast Greenland. In Raasch, G. O. (edit.) Geology of the Arctic 1, 155-159. Toronto U.P.

Haller, J. 1970: Tectonic map of East Greenland (1:500,000). Meddr Grønland 171(5), 286 pp.

Haller, J. 1971: Geology of the East Greenland Caledonides. 413 pp. London: Interscience.

Haller, J. 1983: Geological map of Northeast Greenland 75-82 N Lat. 1:1.000.000. Meddr Grønland 200(5), $22 \mathrm{pp}$.

Henriksen, N. \& Peel, J. S. 1976: Cambrian - Early Ordovician stratigraphy in south-western Washington Land, western North Greenland. Rapp. Grønlands geol. Unders. 80, 17-23.

Higgins, A. K., Friderichsen, J. D. \& Soper, N. J. 1981: The North Greenland fold belt between central Johannes V. Jensen Land and eastern Nansen Land. Rapp. Grønlands geol. Unders. 106, 35-45.

Higgins, A. K., Soper, N. J. \& Friderichsen, J. D. 1985: North Greenland fold belt in eastern North Greenland. In Gee, D. G. \& Sturt, B. A. (edit.) The Caledonide Orogen: Scandinavia and related areas, 1018-1029. John Wiley.

Hurst, J. M. 1984: Upper Ordovician and Silurian carbonate shelf stratigraphy, facies and evolution, eastern North Greenland. Bull. Grønlands geol. Unders. 148, 73 pp.

Hurst, J. M. \& McKerrow, W. S. 1981a: The Caledonian nappes of Kronprins Christian Land, eastern North Greenland. Rapp. Grønlands geol. Unders. 106, 15-19.

Hurst, J. M. \& McKerrow, W. S. 1981b: The Caledonian nappes of eastern North Greenland. Nature, 290, 772-774.

Hurst, J. M. \& Surlyk, F. 1982: Stratigraphy of the Silurian turbidite sequence of North Greenland. Bull. Grønlands geol. Unders. 145, $121 \mathrm{pp}$.

Hurst, J. M. \& Surlyk, F. 1984: Tectonic control of Silurian carbonate-shelf margin morphology and facies, North Greenland. Bull. Am. Ass. Petrol. Geol. 68, 1-17.

Hurst, J. M., McKerrow, W. S., Soper, N. J. \& Surlyk, F. 1983: The relationship between Caledonian nappe tectonics and Silurian turbidite deposition in North Greenland. J. geol. Soc. London 140, 123131.

Ineson, J. R. \& Peel, J. S. 1980; Cambrian stratigraphy in Peary Land, eastern North Greenland. Rapp. Grønlands geol. Unders. 99, 33-49.

Jepsen, H. F. 1971: The Precambrian, Eocambrian and early Palaeozoic stratigraphy of the Jørgen Brønlund Fjord area, Peary Land, North Greenland. Bull. Grønlands geol. Unders. 96 (also Meddr Grønland 192, 2) $42 \mathrm{pp}$.

Jepsen, H. F. \& Kalsbeek, F. 1981: Non-existence of the Carolinidian orogeny in the Prinsesse CarolineMathilde Alper of Kronprins Christian Land, eastern North Greenland. Rapp. Grønlands geol. Unders. 106, 7-14.

Jepsen, H. F. \& Kalsbeek, F. 1985: Evidence for non-existence of a Carolinidian fold belt in eastern North Greenland. In Gee, D. G. \& Sturt, B. A. (edit.) The Caledonide Orogen: Scandinavia and related areas, 1071-1076. John Wiley.

Jepsen, H. F., Kalsbeek, F. \& Suthren, R. J. 1980: The Zig-Zag Dal Basalt Formation, North Greenland. Rapp. Grønlands geol. Unders. 99, 25-32.

Kalsbeek, F. 1981: The northward extent of the Archaean basement of Greenland - a review of Rb-Sr whole-rock ages. Precambrian Res. 14, 203-219. 
Kalsbeek, F. \& Jepsen, H. F. 1980: Preliminary Rb-Sr isotope evidence on the age and metamorphic history of the North Greenland crystalline basement. Rapp. Grønlands geol. Unders. 99, 107-110.

Kalsbeek, F. \& Jepsen, H. F. 1983: The Midsommers $\varnothing$ dolerites and associated intrusions in the Proterozoic platform of eastern North Greenland - a study of the interaction between intrusive basic magma and sialic crust. J. Petrol. 24, 605-634.

Kalsbeek, F. \& Jepsen, H. F. 1984: The late Proterozoic Zig-Zag Dal Basalt Formation of eastern North Greenland. J. Petrol. 25, 644-664.

Koch, L. 1920: Stratigraphy of Northwest Greenland. Meddr dansk geol. Foren. 5(17), 78 pp.

Koch, L. 1929a: Stratigraphy of Greenland. Meddr Grønland 73, 2(2), 205-320.

Koch, L. 1929b: The geology of the south coast of Washington Land. Meddr Grønland 73, 1(1), 39 pp.

Koch, L. 1932: Map of North Greenland. 1:300 000. 19 sheets. Copenhagen: Geodetic Institute.

Krinsley, D. B. 1961: Late Pleistocene glaciation in northeast Greenland. In Raasch, G. O. (edit.) Geology of the Arctic 2, 747-751, Toronto, U.P.

Larsen, O. 1982: The age of the Kap Washington Group volcanics, North Greenland. Bull. geol. Soc. Denmark 31, 49-55.

Larsen, O. \& Graff-Petersen, P. 1980: Sr-isotopic studies and mineral composition of the Hagen Bræ Member in the Proterozoic clastic sediments at Hagen Bra, eastern North Greenland. Rapp. Grønlands geol. Unders. 99, 111-118.

Nathorst, A. G. 1911: Contributions to the Carboniferous flora of North-eastern Greenland. Meddr Grønland 43(12), 337-346.

Nielsen, E. 1941: Remarks on the map and the geology of Kronprins Christians Land. Meddr Grønland 126(2), $34 \mathrm{pp}$.

Parsons, I. 1981: Volcanic centres between Frigg Fjord and Midtkap, eastern North Greenland. Rapp. Grønlands geol. Unders. 106, 69-75.

Pedersen, S. A. S. 1979: Structural geology of central Peary Land, North Greenland. Rapp. Grønlands geol. Unders. 88, 55-62.

Pedersen, S. A. S. 1980: Regional geology and thrust fault tectonics in the southern part of the North Greenland fold belt, north Peary Land. Rapp. Grønlands geol. Unders. 99, 79-87.

Pedersen, S. A. S. 1981: Thrust fault tectonics along the Palaeozoic continental margin of North Greenland: the westernmost structural effect of the Caledonian orogenesis (abstract). Terra Cognita 1, 72 only.

Pedersen, S. A. S. 1982: Structural analysis of the southern margin of the North Greenland fold belt in Peary Land. Unpubl. thesis, University of Copenhagen. $229 \mathrm{pp}$.

Pedersen, S. A. S. \& Holm, P. M. 1983: The significance of a Middle Devonian K/Ar age of an intrusive rock in the southern part of the North Greenland fold belt. Bull. geol. Soc. Denmark 31, 121-127.

Peel, J. S. 1982: The Lower Palaeozoic of Greenland. In Embry, A. F. \& Balkwill, H. R. (edit.) Arctic geology and geophysics. Mem. Can. Soc. Petrol. Geol. 8, 309-330.

Peel, J. S. \& Higgins, A. K. 1980: Fossils from the Paradisfjeld Group, North Greenland fold belt. Rapp. Grønlands geol. Unders. 101, 28 only.

Peel, J. S., Ineson, J. R., Lane, P. D. \& Armstrong, H. A. 1981: Lower Palaeozoic stratigraphy around Danmark Fjord, eastern North Greenland. Rapp. Grønlands geol. Unders. 106, 21-27.

Pickerill, R. K., Hurst, J. M. \& Surlyk, F. 1982: Notes on Lower Palaeozoic flysch trace fossils from Hall Land and Peary Land, North Greenland. Rapp. Grønlands geol. Unders. 108, 25-29.

Schuchert, C. 1923: Sites and nature of the North American geosynclines. Bull. geol. Soc. Am. 34, 151229.

Soper, N. J., Dawes, P. R. \& Higgins, A. K. 1982: Cretaceous - Tertiary magmatic and tectonic events in North Greenland and the history of adjacent ocean basins. In Dawes, P. R. \& Kerr, J. W. (edit.) Nares Strait and the drift of Greenland: a conflict in plate tectonics. Meddr Gronland, Geosci. 8, 205220. 
Soper, N. J., Higgins, A. K. \& Friderichsen, J. D. 1980: The North Greenland fold belt in eastern Johannes V. Jensen Land. Rapp. Grønlands geol. Unders. 99, 89-98.

Surlyk, F. 1982: Nares Strait and the down-current termination of the Silurian turbidite basin of North Greenland. In Dawes, P. R. \& Kerr, J. W. (edit.) Nares Strait and the drift of Greenland: a conflict in plate tectonics. Meddr Grønland, Geosci. 8, 147-150.

Surlyk, F. \& Hurst, J. M. 1983: Evolution of the early Palaeozoic deep-water basin of North Greenland - Aulacogen or narrow ocean. Geology 11, 77-81.

Surlyk, F. \& Hurst, J. M. 1984: The evolution of the early Paleozoic deep-water basin of North Greenland. Bull. geol. Soc. Am. 95, 131-154.

Surlyk, F., Hurst, J. M. \& Bjerreskov, M. 1980: First age-diagnostic fossils from the central part of the North Greenland fold belt. Nature 286, 800-803.

Thorsteinsson, R. \& Tozer, E. T. 1970: The geology of the Arctic Archipelago. In Douglas, R. J. W. (edit.) Geology and economic minerals of Canada. Econ. Geol. Rep. geol. Surv. Can. 1. 547-590.

Trettin, H. P. 1979: Middle Ordovician to Lower Devonian deep-water succession at southeastern margin of Hazen Trough, Canon Fiord, Ellesmere Island. Bull. geol. Surv. Can. 272, 84 pp.

Trettin, H. P. \& Balkwill, H. R. 1979: Contributions to the tectonic history of the Innuitian Province, Arctic Canada. Can. J. Earth Sci. 16, 748-769.

Trettin, H. P., Frisch, T. O., Sobczak, L. W., Weber, J. R., Niblett, E. R., Law, L. K., DeLaurier, J. M. \& Whitlam, K. 1972: The Innuitian Province. In Price, R. A. \& Douglas, R. J. W. (edit.) Variations in tectonic styles in Canada. Spec. Pap. geol. Ass. Can. 11, 83-179.

Troelsen, J. C. 1949: Contributions to the geology of the area round Jørgen Brønlunds Fjord, Peary Land, North Greenland. Meddr Grønland 149(2), 29 pp.

Troelsen, J. (C). 1950: Geology. In Winther, P. C. et al. A preliminary account of the Danish Pearyland Expedition, 1948-9. Arctic 3, 6-8.

Troelsen, J. C. 1956: The Cambrian of North Greenland and Ellesmere Island. In: El sistema Cambrico su paleogeografia y el problema du base. 20 Congr. geol. int. Mexico. Symp. 3(1), 71-90.

Wagner, R. H., Soper, N. J. \& Higgins, A. K. 1982: A late Permian flora of Pechora affinity in North Greenland. Rapp. Grønlands geol. Unders. 108, 5-13.

Weidick, A. 1976: Quaternary observations in southern Peary Land, North Greenland. Rapp. Grønlands geol. Unders. 80, 15-17. 